
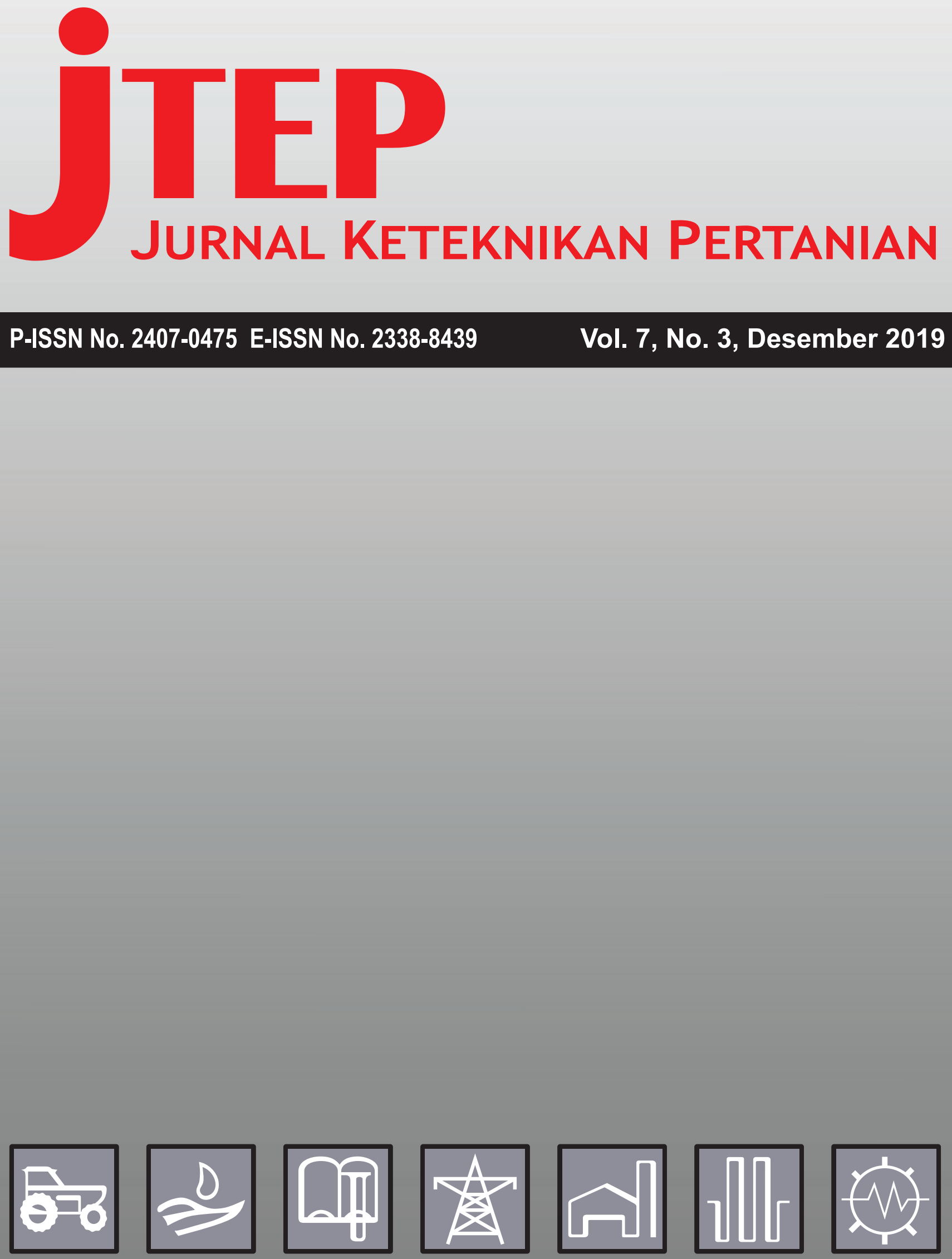

Publikasi Resmi
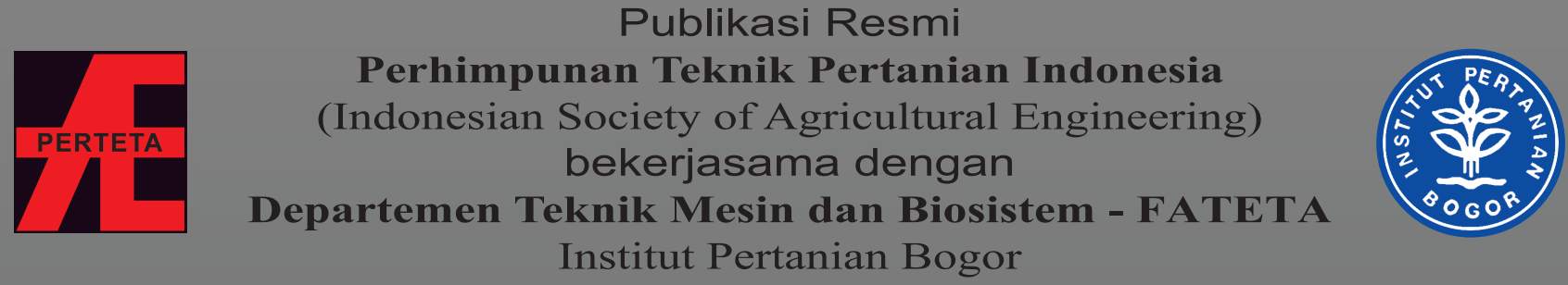


\section{jteP JURnal Keteknikan PERTANIAN}

Vol. 7, No. 3. Desember 2019

Jurnal Keteknikan Pertanian (JTEP) terakreditasi berdasarkan SK Dirjen Penguatan Riset dan Pengembangan Kementerian Ristek Dikti Nomor I/E/KPT/2015 tanggal 21 September 2015. Selain itu, JTEP juga telah terdaftar pada Crossref dan telah memiliki Digital Object Identifier (DOI) dan telah terindeks pada ISJD, IPI, Google Scholar dan DOAJ. JTEP terbit tiga kali setahun yaitu bulan April, Agustus dan Desember, Jurnal berkala ilmiah ini berkiprah dalam pengembangan ilmu keteknikan untuk pertanian tropika dan lingkungan hayati. Penulis makalah tidak dibatasi pada anggota PERTETA tetapi terbuka bagi masyarakat umum. Lingkup makalah, antara lain meliputi teknik sumberdaya lahan dan air, alat dan mesin budidaya pertanian, lingkungan dan bangunan pertanian, energi alternatif dan elektrifikasi, ergonomika dan elektronika pertanian, teknik pengolahan pangan dan hasil pertanian, manajemen dan sistem informasi pertanian. Makalah dikelompokkan dalam invited paper yang menyajikan isu aktual nasional dan internasional, review perkembangan penelitian, atau penerapan ilmu dan teknologi, technical paper hasil penelitian, penerapan, atau diseminasi, serta research methodology berkaitan pengembangan modul, metode, prosedur, program aplikasi, dan lain sebagainya. Penulisan naskah harus mengikuti panduan penulisan seperti tercantum pada website dan naskah dikirim secara elektronik (online submission) melalui http://journal.ipb.ac.id/index.php/jtep.

\section{Penanggungjawab:}

Ketua Departemen Teknik Mesin dan Biosistem, Fakultas Teknologi Pertanian,IPB

Ketua Perhimpunan Teknik Pertanian Indonesia

\section{Dewan Redaksi:}

Ketua : Yohanes Aris Purwanto (Scopus ID: 6506369700, IPB University)

Anggota : Abdul Hamid Adom (Scopus ID: 6506600412, University Malaysia Perlis)

(editorial Addy Wahyudie (Scopus ID: 35306119500, United Arab Emirates University)

board) Budi Indra Setiawan (Scopus ID: 55574122266, IPB University)

Balasuriya M.S. Jinendra (Scopus ID: 30467710700 , University of Ruhuna)

Bambang Purwantana (Scopus ID: 6506901423, Universitas Gadjah Mada)

Bambang Susilo (Scopus ID: 54418036400, Universitas Brawijaya)

Daniel Saputera (Scopus ID: 6507392012, Universitas Sriwjaya)

Han Shuqing (Scopus ID: 55039915600, China Agricultural University)

Hiroshi Shimizu (Scopus ID: 7404366016, Kyoto University)

I Made Anom Sutrisna Wijaya (Scopus ID: 56530783200, Universitas Udayana)

Agus Arif Munawar (Scopus ID: 56515099300, Universitas Syahkuala)

Armansyah H. Tambunan (Scopus ID: 57196349366, IPB University)

Kudang Boro Seminar (Scopus ID: 54897890200, IPB University)

M. Rahman (Scopus ID: 7404134933, Bangladesh Agricultural University)

Machmud Achmad (Scopus ID: 57191342583, Universitas Hasanuddin)

Muhammad Makky (Scopus ID: 55630259900, Universitas Andalas)

Muhammad Yulianto (Scopus ID: 54407688300, IPB University \& Waseda University)

Nanik Purwanti (Scopus ID: 23101232200, IPB University \& Teagasc Food Research Center Irlandia)

Pastor P. Garcia (Scopus ID: 57188872339 , Visayas State University)

Rosnah Shamsudin (Scopus ID: 6507783529, Universitas Putra Malaysia)

Salengke (Scopus ID: 6507093353, Universitas Hasanuddin)

Sate Sampattagul (Scopus ID: 7801640861, Chiang Mai University)

Subramaniam Sathivel (Scopus ID: 6602242315, Louisiana State University)

Shinichiro Kuroki (Scopus ID: 57052393500 , Kobe University)

Siswoyo Soekarno (Scopus ID: 57200222075 , Universitas Jember)

Tetsuya Araki (Scopus ID: 55628028600, The University of Tokyo)

Tusan Park (Scopus ID: 57202780408, Kyungpook National University) 


\section{Redaksi Pelaksana:}

Ketua : Usman Ahmad (Scopus ID: 55947981500, IPB University)

Sekretaris : Lenny Saulia (Scopus ID: 16744818700, IPB University)

Bendahara : Dyah Wulandani (Scopus ID: 1883926600, IPB University)

Anggota : Satyanto Krido Saptomo (Scopus ID: 6507219391, IPB University)

Slamet Widodo (Scopus ID: 22636442900, IPB University)

Liyantono (Scopus ID: 54906200300, IPB University)

Leopold Oscar Nelwan (Scopus ID: 56088768900, IPB University)

I Wayan Astika (Scopus ID: 43461110500, IPB University)

Agus Ghautsun Niam (Scopus ID: 57205687481, IPB University)

Administrasi : Diana Nursolehat (IPB University)

Penerbit: Perhimpunan Teknik Pertanian Indonesia (PERTETA) bekerjasama dengan Departemen Teknik Mesin dan Biosistem, Institut Pertanian Bogor.

Alamat: Jurnal Keteknikan Pertanian, Departemen Teknik Mesin dan Biosistem, Fakultas Teknologi Pertanian, Kampus Institut Pertanian Bogor, Bogor 16680.

Telp. 0251-8624 503, Fax 0251-8623 026,

E-mail: jtep@ipb.ac.id atau jurnaltep@yahoo.com

Website: web.ipb.ac.id/ jtep atau http://journal.ipb.ac.id/index.php/jtep

Rekening: BRI, KCP-IPB, No.0595-01-003461-50-9 a/n: Jurnal Keteknikan Pertanian

Percetakan: PT. Binakerta Makmur Saputra, Jakarta 


\section{Ucapan Terima Kasih}

Redaksi Jurnal Keteknikan Pertanian mengucapkan terima kasih kepada para Mitra Bebestari yang telah menelaah (me-review) Naskah pada penerbitan Vol. 7 No. 3 Desember 2019. Ucapan terima kasih disampaikan kepada: Prof.Dr.Ir. Bambang Purwantana, M.Agr (Fakultas Teknologi Pertanian, Universitas Gadjah Mada), Dr.Ir. Nugroho Tri Waskito, MP (Fakultas Pertanian dan Peternakan, Universitas Muhammadiyah Malang), Dr. Ardiansyah, S.TP, M.Si (Fakultas Pertanian, Universitas Jenderal Soedirman), Dr. Ridwan Rahmat (Balai Penelitian Pasca Panen Cimanggu), Prof.Dr.Ir. Budi Indra Setiawan, M.Agr. (Departemen Teknik Sipil dan Lingkungan, Fakultas Teknologi Pertanian, Institut Pertanian Bogor), Prof.Dr.Ir. Sutrisno M.Agr (Departemen Teknik Mesin dan Biosistem, Fakultas Teknologi Pertanian, Institut Pertanian Bogor), Dr.Ir. Wawan Hermawan, MS (Departemen Teknik Mesin dan Biosistem, Fakultas Teknologi Pertanian, Institut Pertanian Bogor), Dr.Ir. Dyah Wulandani, MSi (Departemen Teknik Mesin dan Biosistem, Fakultas Teknologi Pertanian, Institut Pertanian Bogor), Dr. Slamet Widodo, S.TP, M.Sc (Departemen Teknik Mesin dan Biosistem, Fakultas Teknologi Pertanian, Institut Pertanian Bogor), Dr. Liyantono, S.TP, M.Agr (Departemen Teknik Mesin dan Biosistem, Fakultas Teknologi Pertanian, Institut Pertanian Bogor) 


\title{
Pengaruh Pengolahan Tanah dan Penambahan Jerami Terhadap Kebutuhan Air Penyiapan Lahan Padi Sawah
}

\author{
Effect of Soil Tillage and Rice Straw Addition to the Water Requirement of Preparing Paddy Fields
}

\author{
Delvi Yanti, Fakultas Teknologi Pertanian, Univeristas Andalas. Email: delviyanti@ae.unand.ac.id \\ Tineke Mandang, Departemen Teknik Mesin dan Biosistem, Institut Pertanian Bogor. \\ Email: tineke_mandang_2003@yahoo.com \\ Mohamad Yanuar Jawardi Purwanto, Departemen Teknik Sipil dan Lingkungan, Institut Pertanian Bogor. \\ Email: Yanuar.tta@gmail.com \\ Mohamad Solahudin, Departemen Teknik Mesin dan Biosistem, Institut Pertanian Bogor. \\ Email: msoul9@yahoo.com
}

\begin{abstract}
Management practices such as soil tillage, mulch, and fertilization are carried out to improve the soil physical environment with the ultimate goal of increasing crop productivity. The purpose of this study is to determine the effect of soil tillage and the addition of rice straw to the physical properties of the soil and water requirements for preparing paddy fields. The research design used was a factorial Completely Randomized Design (CRD) consisting of two treatment factors, i.e. soil tillage and the addition of rice straw. Each of which was carried out 3 times. The soil tillage, i.e. plowing-puddling is conducted in two stages or there is a gap for 15 days (PT1) and plowing-puddling is conducted in one activity stage or without pause (PT2), whereas for the treatment of rice straw addition it was done with no straw (JO) and using a straw (J1). The observations were carried out on the physical properties of the soil by sampling intact soils before and after conducting the soil tillage. Calculations of the water requirements for land preparation are made for each treatment. To determine the effect of the treatment on the soil's physical properties and the water requirements for the land preparation, a variety of analysis (ANOVA) is conducted. If there are differences in the results between treatments, a Duncan test is made at a significant level of 5\%. The results of the experiment are soil processing and the addition of rice straw affects the physical properties of the soil and the water preparation needs of the land, but there is no interaction between the two factors. Two-stage soil treatment tillage and the addition of rice straw are treatments that require the most water in land preparation that is equal to $196.95 \mathrm{~mm}$ even though it is the best treatment with available water of $16 \%$.
\end{abstract}

Keywords: land cultivation; land preparation; lowland rice; rice straw; water requirements

\begin{abstract}
Abstrak
Praktik manajemen seperti pengolahan tanah, mulsa, dan pemupukan dilakukan untuk meningkatkan lingkungan fisik tanah dengan tujuan akhir untuk meningkatkan produktivitas tanaman. Tujuan penelitian ini adalah untuk mengetahui pengaruh pengolahan tanah dan penambahan jerami terhadap sifat fisik tanah dan kebutuhan air penyiapan lahan padi sawah. Rancangan penelitian yang digunakan adalah Rancangan Acak Lengkap (RAL) faktorial yang terdiri dari dua faktor perlakuan, yaitu pengolahan tanah dan penambahan jerami yang masingmasing dilakukan 3 kali. Perlakuan pengolahan tanah yaitu pembajakan-pelumpuran dilakukan dengan dua tahap atau ada jeda selama 15 hari $\left(\mathrm{PT}_{1}\right)$ dan pembajakan-pelumpuran dilakukan dalam satu tahap kegiatan atau tanpa ada jeda $\left(\mathrm{PT}_{2}\right)$, sedangkan untuk perlakukan jerami, ada yang tanpa jerami $\left(\mathrm{J}_{0}\right)$ dan menggunakan jerami $\left(\mathrm{J}_{1}\right)$. Pengamatan dilakukan terhadap sifat fisik tanah dengan cara pengambilan contoh tanah utuh sebelum dan setelah dilakukannya pengolahan tanah. Perhitungan terhadap kebutuhan air penyiapan lahan dilakukan untuk masing-masing perlakuan. Untuk mengetahui pengaruh perlakuan terhadap sifat fisik tanah dan kebutuhan air penyiapan lahan dilakukan analisis ragam (anova), jika ada perbedaan hasil antar perlakuan dilakukan uji lanjut duncan pada taraf nyata $5 \%$. Hasil percobaan yaitu pengolahan tanah dan penambahan jerami berpengaruh terhadap sifat fisik tanah dan kebutuhan air penyiapan lahan, tetapi tidak ada interaksi antara kedua faktor tersebut. Pengolahan tanah dua tahap dan penambahan jerami merupakan perlakuan yang membutuhkan air paling banyak dalam penyiapan lahan yaitu sebesar $196,95 \mathrm{~mm}$, tetapi merupakan perlakuan terbaik dengan air tersedia sebesar $16 \%$.
\end{abstract}

Kata kunci: jerami; kebutuhan air; padi sawah; pengolahan tanah; penyiapan lahan. 


\section{Latar Belakang}

Tanah adalah media dasar untuk perkecambahan biji, kemunculan benih, pertumbuhan akar dan akhirnya produksi tanaman (Khan et al., 2010). Praktik manajemen seperti pengolahan tanah, pemberian mulsa, dan pemupukan dilakukan untuk meningkatkan lingkungan fisik tanah dengan tujuan akhir untuk meningkatkan produktivitas tanaman.

Manajemen pengolahan tanah dan penerapan pupuk adalah beberapa faktor penting yang mempengaruhi sifat fisik tanah. Pengolahan tanah dan pupuk kandang sering memiliki efek signifikan pada kepadatan, kelembaban, dan porositas tanah. Pengolahan tanah adalah praktik yang dilakukan untuk melonggarkan tanah dan menghasilkan panen yang baik. $\mathrm{Di}$ antara faktor produksi pengolahan tanah berkontribusi hingga 20\% (Ahmad et al., 1996; Mahajan, 1996; Khan et al., 2010).

Metode pengolahan mempengaruhi sumber daya berkelanjutan melalui pengaruhnya terhadap sifatsifat tanah (Hammel 1989; Nazeer and Malik, 2011). Tanah yang merupakan media pertumbuhan tanaman memiliki sifat yang berbeda. Sifat fisik termasuk; tekstur tanah, struktur, bulk density, porositas dan laju infiltrasi. Sifat-sifat tanah harus menguntungkan bagi pertumbuhan tanaman (Khan et al., 2010).

Di Indonesia, secara umum pengolahan tanah sawah dilakukan dua tahap yang lebih dikenal dengan pembajakan dan pelumpuran. Setelah dibajak, biasanya tanah dibiarkan selama 10-15 hari, kemudian dilanjutkan dengan pelumpuran. Metode pengolahan tanah seperti ini, tidak selalu bisa dan tidak di seluruh wilayah Indonesia bisa diterapkan, karena kegiatan pengolahan tanah membutuhkan air yang banyak, sehingga proses pengolahan tanah sangat dipengaruhi oleh ketersediaan air.

Permasalahan air irigasi yang saat ini cendrung tidak tepat jumlah, tidak tepat waktu, dan tidak tepat lokasi, menjadi faktor pendorong petani untuk melakukan pembajakan dan pelumpuran dalam satu tahap proses kegiatan. Sementara menurut Hartatik \& Setyorini (tahun tidak diketahui) pengolahan tanah (pembajakan dan pelumpuran dilakukan dua tahap) dengan tujuan untuk memberikan kondisi tanah yang baik untuk perakaran padi agar berkembang secara optimal selain berfungsi dalam mematikan gulma.

Disisi lain bahan organik tanah merupakan komponen penting dari kualitas tanah karena menentukan karakteristik tanah seperti mineralisasi nutrisi, stabilitas agregat, aerasi, penyerapan air yang baik dan sifat retensi. Bahan organik tidak hanya meningkatkan kapasitas penahanan air tanah tetapi juga porsi air yang tersedia untuk pertumbuhan tanaman dan meningkatkan sifat fisik tanah. (Epstien et al. 1976; Pagliai et al. 1981; Korentajer 1991; Bolan et al. 2004; Sial et al. 2007; Khan et al. 2010).

Sumber utama bahan organik pada lahan pertanian adalah sisa tanaman yaitu jerami. Sementara kebiasaan sebagian besar petani di Indonesia adalah membakar sisa tanaman atau jerami, atau diangkut ke luar areal pertanian untuk pakan ternak maupun keperluan lainnya. Banyak faktor yang menyebabkan petani belum memanfaatkan jerami sebagai sumber bahan organik dalam budidaya padi sawah, salah satunya adalah mengejar waktu tanam.

Metode pengolahan dan penambahan jerami berpengaruh terhadap sifat fisik tanah, yang merupakan faktor penting dalam menentukan kebutuhan air selama penyiapan lahan padi sawah. Berdasarkan permasalahan di atas, maka tujuan penelitian ini adalah untuk mengetahui pengaruh pengolahan tanah dan penambahan jerami terhadap kebutuhan air penyiapan lahan padi sawah.

\section{Bahan dan Metode}

\section{Lokasi dan Waktu Penelitian}

Penelitian dilakukan pada sawah percobaan Institut Pertanian Bogor, Desa Cikarawang Kecamatan Dramaga Kabupaten Bogor Jawa Barat. Analisis tanah dilakukan di Laboratorium Fisika Tanah Fakultas Pertanian Institut Pertanian Bogor. Penelitian dilaksanakan pada bulan November sampai dengan Desember 2018.

\section{Bahan dan Alat}

Bahan yang digunakan adalah jerami segar yang telah dipotong-potong sebanyak $720 \mathrm{~kg}$, yang digunakan pada 6 petak percobaan. Alat yang digunakan adalah lysimeter tertutup, ring sampel, dan alat pengolah tanah (traktor tangan). Implemen yang digunakan pada traktor tangan adalah bajak singkal untuk kegiatan pembajakan dan gelebeg untuk kegiatan pelumpuran. Merk/model traktor tangan adalah Quick/G1000 Boxer, merk/model diesel motor penggerak adalah Kuboto/RD 85 DI-2T dengan tenaga maksimum $85, \mathrm{HP}$

\section{Rancangan Percobaan dan Perlakuan}

Rancangan percobaan yang digunakan adalah split plot dengan rancangan lingkungan RAL (rancangan acak lengkap) yang menggunakan dua faktor (petak utama dan anak petak), yaitu pengolahan tanah (petak utama) dan penambahan jerami (anak petak) dengan 3 ulangan. Faktor pengolahan tanah yang digunakan adalah: 1) pembajakan-pelumpuran yang dilakukan dengan dua tahap atau ada jeda selama 15 hari $\left(\mathrm{PT}_{1}\right)$; 2) pembajakan-pelumpuran dilakukan dalam satu tahap kegiatan atau tanpa ada jeda $\left(\mathrm{PT}_{2}\right)$. Sementara perlakukan jerami, yaitu: 1) tanpa jerami $\left(\mathrm{J}_{0}\right)$; 2) menggunakan jerami $\left(\mathrm{J}_{1}\right)$.

Pola kerja yang digunakan pada kegiatan pembajakan dan pelumpuran adalah pola tepi dengan banyaknya lintasan bervariasi (kondisional). Pola kerja pada kegiatan pembajakan maupun pelumpuran mengikuti arah panjang petakan lahan, untuk 
Tabel 1. Hasil pengukuran pada kegiatan pengolahan tanah dengan traktor tangan

\begin{tabular}{cccc}
\hline \multirow{2}{*}{ Perlakuan } & \multicolumn{2}{c}{ Kecepatan kerja rata-rata $(\mathrm{m} /$ det $)$} & \multirow{2}{*}{ Kedalaman olah rata-rata $(\mathrm{cm})$} \\
\cline { 2 - 3 } & Pembajakan & Pelumpuran & 19 \\
$\mathrm{PT}_{1} \mathrm{~J}_{0}$ & 0.694 & 0.854 & 17 \\
$\mathrm{PT}_{1} \mathrm{~J}_{1}$ & 0.704 & 0.859 & 25 \\
$\mathrm{PT}_{2} \mathrm{~J}_{0}$ & 0.709 & 0.840 & 20 \\
$\mathrm{PT}_{2} \mathrm{~J}_{1}$ & 0.720 & 0.841 & \\
\hline
\end{tabular}

mengurangi banyaknya belokan. Kecepatan kerja traktor tangan dan kedalaman olah masing-masing perlakuan disajikan pada Tabel 1.

\section{Prosedur Percobaan}

Petakan percobaan dibuat sebanyak 12 buah, dengan ukuran $11.8 \mathrm{~m}$ x $6.5 \mathrm{~m}$. Diagram alir percobaan disajikan pada Gambar 1 dan desain percobaan disajikan pada Gambar 2 dengan rincian perlakukan sebagai berikut:

1. $P T_{1} J_{0}$ (pembajakan-pelumpuran yang dilakukan satu tahap dan tidak menggunakan jerami).

2. $P T_{1} J_{1}$ (pembajakan-pelumpuran yang dilakukan satu tahap dan menggunakan jerami).

3. $P T_{2} J_{0}$ (pembajakan-pelumpuran yang dilakukan dua tahap dan tidak menggunakan jerami).

4. $P T_{2} J_{1}$ (pembajakan-pelumpuran yang dilakukan dua tahap dan meggunakan jerami).

\section{Pengamatan sifat fisik tanah}

Pengamatan sifat fisik tanah dengan cara pengambilan contoh tanah utuh sebelum dan setelah pengolahan tanah menggunakan ring sample, masingmasing perlakuan 3 ulangan. Ring sample yang digunakan mempunyai ukuran tinggi $4 \mathrm{~cm}$, diameter dalam $7.63 \mathrm{~cm}$, diameter luar $7.93 \mathrm{~cm}$, dan tabung ditutup dengan plastik di kedua ujungnya. Contoh tanah utuh diambil pada kedalaman $10-20 \mathrm{~cm}$ dari permukaan tanah. Pengambilan contoh tanah utuh dilakukan secara acak sederhana/ simple random sampling (SRS) yaitu metode Systematic sampling (SyS). Pengambilan contoh tanah utuh sebelum tanah diolah diambil 1 hari sebelum pengolahan tanah dilakukan dan pengambilan contoh tanah utuh setelah tanah diolah dilakukan 30 hari setelah pengolahan tanah pertama.

Analisis laboratorium dilakukan untuk mengetahui sifat-sifat fisik tanah, mencakup tekstur tanah, kadar air (\%)sebelum dan setelah pengolahan tanah, kerapatan isi (BD), berat jenis partikel (PD), ruang pori total (RPT), dan kadar air tanah (pF1, pF2, pF2,54, $\mathrm{pF} 4,2)$, pori drainase cepat dan lambat, air tersedia, dan permeabilitas tanah.

\section{Pengukuran kebutuhan air penyiapan lahan}

Pengukuran kebutuhan air penyiapan lahan dilakukan untuk masing-masing perlakuan. Secara empiris dapat dihitung dengan menggunakan persamaan:

$$
S=\frac{\left(S_{a}-S_{b}\right) N . d .}{10^{4}}+P_{d}+F_{1}
$$

dengan,

$S$ : kebutuhan air penyiapan lahan $(\mathrm{mm})$

$S_{a}$ : kadar air setelah pelumpuran (\%)

$S_{b}$ : kadar air sebelum pelumpuran (\%)

$N$ : porositas tanah (\%)

$d$ : kedalaman lapisan tanah yang dilumpurkan $(\mathrm{mm})$

$P_{d}$ : tinggi genangan di petakan $(50 \mathrm{~mm})$

$F_{1}$ : kehilangan air selama pelumpuran $(\mathrm{mm})$ yaitu evaporasi dan perkolasi

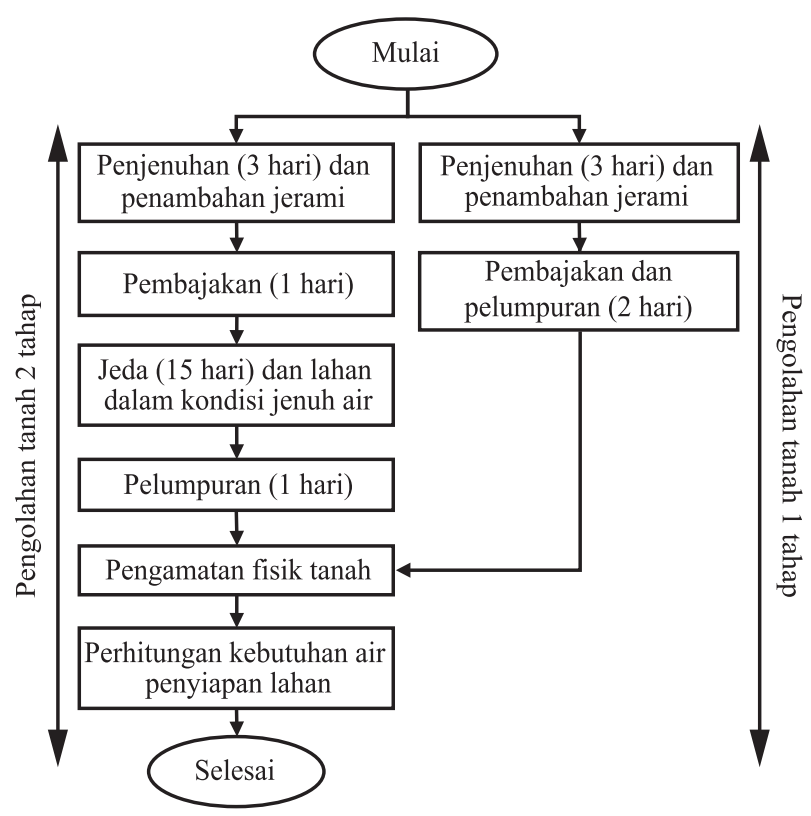

Gambar 1. Diagram alir percobaan.

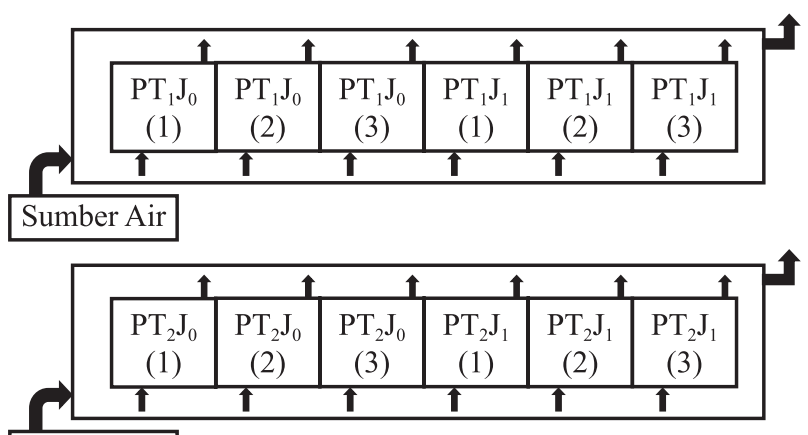

Sumber Air

Gambar 2. Desain percobaan. 
Tabel 3. Pengaruh Pengolahan Tanah dan Penambahan Jerami terhadap Sifat Fisik Tanah

\begin{tabular}{|c|c|c|c|c|c|c|c|c|c|c|c|}
\hline & \multirow{2}{*}{$\begin{array}{l}\mathrm{BD} \\
(\mathrm{g} / \mathrm{cc})\end{array}$} & \multirow{2}{*}{$\begin{array}{c}\mathrm{PD} \\
(\mathrm{g} / \mathrm{cc})\end{array}$} & RTP & $\mathrm{pF} 1$ & $\mathrm{pF} 2$ & $\mathrm{pF} 2.54$ & $\mathrm{pF} 4.2$ & PDC & PDL & AT & \multirow{2}{*}{$\begin{array}{l}\text { Permeabilitas } \\
\text { (cm/jam) }\end{array}$} \\
\hline & & & \multicolumn{8}{|c|}{$(\% \mathrm{Vol})$} & \\
\hline \multicolumn{12}{|l|}{ Faktor A } \\
\hline $\mathrm{PT}_{1}$ & $0.92 \pm 0.02_{\mathrm{a}}$ & $2.23 \pm 0.03_{\mathrm{a}}$ & $58.93 \pm 1.32_{\mathrm{a}}$ & $50.53 \pm 0.92_{a}$ & $45.78 \pm 0.6_{a}$ & $41.90 \pm 0.25_{\mathrm{a}}$ & $26.85 \pm 0.94_{a}$ & $13.15 \pm 1.22_{\mathrm{a}}$ & $3.88 \pm 0.38_{\mathrm{a}}$ & $15.05 \pm 0.96_{\mathrm{a}}$ & $1.23 \pm 0.13_{\mathrm{a}}$ \\
\hline $\mathrm{PT}_{2}$ & $0.87 \pm 0.02_{\mathrm{b}}$ & $2.20 \pm 0.06_{\mathrm{a}}$ & $60.38 \pm 1.52_{\mathrm{a}}$ & $48.15 \pm 1.6_{b}$ & $43.40 \pm 1.33_{b}$ & $40.27 \pm 0.96 \mathrm{~b}$ & $24.57 \pm 1.14_{b}$ & $16.98 \pm 2.07_{\mathrm{b}}$ & $3.13 \pm 0.62_{b}$ & $15.70 \pm 0.41_{\mathrm{b}}$ & $3.38 \pm 0.11_{b}$ \\
\hline \multicolumn{12}{|c|}{ 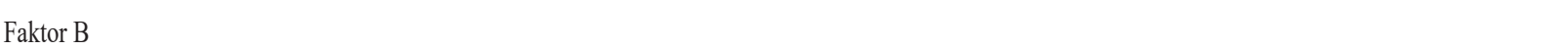 } \\
\hline $\mathrm{J}_{0}$ & $0.90 \pm 0.02_{\mathrm{a}}$ & $2.23 \pm 0.05_{\mathrm{a}}$ & $59.52 \pm 1.53_{\mathrm{a}}$ & $50.35 \pm 0.98_{\mathrm{a}}$ & $45.33 \pm 1.27 \mathrm{a}$ & $41.52 \pm 0.83_{\mathrm{a}}$ & $26.57 \pm 1.22_{\mathrm{a}}$ & $14.18 \pm 2.02_{\mathrm{a}}$ & $3.82 \pm 0.62_{a}$ & $14.95 \pm 0.52_{\mathrm{a}}$ & $2.24 \pm 1.23_{\mathrm{a}}$ \\
\hline $\mathrm{J}_{1}$ & $0.89 \pm 0.03_{\mathrm{a}}$ & $2.20 \pm 0.05_{\mathrm{a}}$ & $59.80 \pm 1.72_{\mathrm{a}}$ & $48.33 \pm 1.85_{b}$ & $43.85 \pm 1.61_{b}$ & $40.65 \pm 1.2 \mathrm{~b}$ & $24.85 \pm 1.43_{\mathrm{b}}$ & $15.95 \pm 2.96_{a}$ & $3.20 \pm 0.5_{\mathrm{a}}$ & $15.80 \pm 0.45_{\mathrm{b}}$ & $2.37 \pm 1.13_{\mathrm{b}}$ \\
\hline \multicolumn{12}{|c|}{ Faktor A x B } \\
\hline $\mathrm{PT}_{1} \mathrm{~J}_{0}$ & $0.92 \pm 0.02_{-}$ & $2.24 \pm 0.03_{-}$ & $59.1 \pm 1.35_{-}$ & $51.1 \pm 0.79_{+}$ & $46.27 \pm 0.25$ & $42.1 \pm 0.10_{-}$ & $27.6 \pm 0.26_{-}$ & $12.8 \pm 1.29$ & $4.17 \pm 0.23_{-}$ & $14.5 \pm 0.20_{-}$ & $1.11 \pm 0.02_{-}$ \\
\hline $\mathrm{PT}_{1} \mathrm{~J}_{1}$ & $0.91 \pm 0.02_{-}$ & $2.22 \pm 0.04$ & $58.8 \pm 1.56_{-}$ & $50.0 \pm 0.71_{+}$ & $45.30 \pm 0.36$ & $41.7 \pm 0.17$ & $26.1 \pm 0.66_{-}$ & $13.5 \pm 1.30_{-}$ & $3.60 \pm 0.26_{-}$ & $15.6 \pm 0.50_{-}$ & $1.34 \pm 0.04$ \\
\hline $\mathrm{PT}_{2} \mathrm{~J}_{0}$ & $0.89 \pm 0.02_{-}$ & $2.22 \pm 0.07$ & $60.0 \pm 1.85_{-}$ & $49.6 \pm 0.26_{+}$ & $44.40 \pm 1.15$ & $40.9 \pm 0.83_{-}$ & $25.5 \pm 0.67$ _ & $15.6 \pm 1.68$ & $3.47 \pm 0.74$ & $15.4 \pm 0.17_{-}$ & $3.36 \pm 0.04$ \\
\hline $\mathrm{PT}_{2} \mathrm{~J}_{1}$ & $0.86 \pm 0.01_{-}$ & $2.19 \pm 0.06_{-}$ & $60.9 \pm 1.30_{-}$ & $46.7 \pm 0.17_{+}$ & $42.40 \pm 0.26$ & $39.6 \pm 0.53$ & $23.6 \pm 0.17_{-}$ & $18.5 \pm 1.26_{-}$ & $2.80 \pm 0.26_{-}$ & $16.0 \pm 0.36_{-}$ & $3.39 \pm 0.16_{-}$ \\
\hline
\end{tabular}

Keterangan: Angka-angka yang diikuti huruf tidak sama pada kolom yang sama menunjukkan berbeda nyata pada taraf $5 \%$ Uji Jarak Berganda Duncan (DMRT) dan tanda (-) menunjukkan tidak ada interaksi

Tabel 2. Pengamatan sifat fisik tanah sebelum pengolahan tanah

\begin{tabular}{lc}
\hline \multicolumn{1}{c}{ Sifat fisik tanah } & $\begin{array}{c}\text { Sebelum } \\
\text { pengolahan tanah }\end{array}$ \\
\hline Kerapatan isi (BD) (g/cc) & $1.01 \pm 0.02$ \\
Berat jenis partikel (PD) (g/cc) & $2.34 \pm 0.06$ \\
Ruang Pori Total $(\% \mathrm{vol})$ & $56.9 \pm 1.86$ \\
Kadar air (\% vol) & \\
$\quad$ - pF1 & $57.4 \pm 1.06$ \\
- pF2 & $48.90 \pm 0.30$ \\
- pF2,54 & $43.47 \pm 0.15$ \\
- pF4,2 & $29.60 \pm 0.26$ \\
Pori drainase (\% vol) & \\
- Cepat & $8.0 \pm 1.73$ \\
- Lambat & $5.43 \pm 0.15$ \\
Air tersedia (\% vol) & $13.9 \pm 0.12$ \\
Permeabilitas (cm/jam) & $0.61 \pm 0.02$ \\
\hline
\end{tabular}

Data evaporasi terbuka menggunakan data sekunder (BMKG Stasiun Klimatologi Dramaga Bogor) dan laju perkolasi dilakukan pengukuran langsung di lapang menggunakan lysimeter. Lysimeter terbuat dari drum dengan diameter $45 \mathrm{~cm}$ dan tinggi $60 \mathrm{~cm}$. Lysimeter dimasukkan kedalam tanah kurang lebih $30 \mathrm{~cm}$. lysimeter diisi air dengan ketinggian kurang lebih sama dengan ketinggian air di luar lysimeter. Kehilangan air dalam lysimeter diukur dengan menggunakan mistar setiap hari pada jam yang sama yaitu pada pukul 07.00 WIB.

Data kadar air sebelum dan setelah pengolahan tanah, serta porositas tanah merupakan hasil analisis laboratorium. Pengukuran kedalaman lapisan tanah yang dilumpurkan dimulai dari permukaan lumpur sampai pada batas tanah tak terolah, yang dilakukan setelah kegiatan pelumpuran selesai.

\section{Analisis Data}

Untuk mengetahui pengaruh perlakuan terhadap sifat fisik tanah dan kebutuhan air penyiapan lahan, maka dilakukan analisis ragam (Anova) dua arah dengan software SPSS (Statistical Package for the Social Sciences). Hipotesis penelitian adalah tidak ada penggaruh pengolahan tanah dan penambahan jerami terhadap kebutuhan air penyiapan lahan padi sawah. Apabila perlakuan berpengaruh nyata, maka dilanjutkan dengan uji DNMRT pada taraf nyata $5 \%$.

\section{Hasil dan Pembahasan}

\section{Parameter fisika tanah pada berbagai perlakuan pengolahan tanah}

Tekstur tanah berpengaruh terhadap kemampuan tanah dalam menahan air. Menurut Hanafiah (2005), tekstur tanah sangat berpengaruh terhadap besar aerasi, ketersediaan air dalam tanah, kemampuan daya serap air, infiltrasi, laju pergerakan air (perkolasi) dan mempengaruhi perkembangan perakaran dan pertumbuhan tanaman serta efisiensi dalam pemakaian air irigasi. Dari hasil uji laboratorium didapatkan bahwa tanah sawah tempat pelaksanaan percobaan bertekstur liat. Tanah bertekstur liat tidak hanya memiliki permukaan yang luas tetapi juga bermuatan listrik. Muatan listrik memberi sifat pada liat untuk dapat mengikat air maupun hara tanaman pada permukaannya. Inilah yang menyebabkan liat lebih banyak menyimpan air (Dixon, 1991; Yazid Ismi Intara, Sapei, Erizal, Sembiring, 2011). Tabel 2 merupakan nilai rataan hasil pengamatan sifat fisik tanah sebelum dilakuan pengolahan berdasarkan 3 kali ulangan. Pengaruh pengolahan tanah dan penambahan jerami terhadap sifat fisik tanah disajikan pada Tabel 3.

Pada Tabel 3 dapat dilihat pengolahan tanah berpengaruh nyata $(P<0.05)$ terhadap nilai kerapatan isi (BD), pF1, pF2, pF2.54, pF4.2, PDC, PDL, AT, dan permeabilitas. Sedangkan penambahan jerami berpengaruh nyata $(\mathrm{P}<0.05)$ terhadap $\mathrm{pF} 1, \mathrm{pF} 2$, pF2.54, pF4.2, AT, dan permeabilitas. Interaksi antara pengolahan tanah dan penambahan jerami hanya terjadi terhadap sifat fisik tanah kondisi air pF1. Salah 
satu penyebab belum adanya pengaruh interaksi antara pengolahan tanah dan penambahan jerami adalah karena jerami yang digunakan merupakan jerami segar. Pada saat pengamatan sifat fisik tanah setelah pengolahan tanah (30 hari dari pengolahan awal), jerami baru mengalami masa dekomposisi. Sebagaimana dikemukakan oleh Sarawati \& Husen (2007), Proses perombakan bahan organik yang terjadi secara alami akan membutuhkan waktu relatif lama (2 bulan). Sanchez (2010), juga mengemukakan bahwa jerami padi memiliki kandungan lignin yang cukup tinggi sehingga sulit terurai secara alami.

Tanah yang diolah dua tahap memiliki kerapatan isi yang lebih rendah dibandingkan dengan tanah yang diolah satu tahap, $\mathrm{PT}_{2} \mathrm{~J}_{0}(0.89 \mathrm{~g} / \mathrm{cc})<\mathrm{PT}_{1} \mathrm{~J}_{0}(0.92 \mathrm{~g} /$ cc) dan $\mathrm{PT}_{2} \mathrm{~J}_{1}(0.86 \mathrm{~g} / \mathrm{cc})<\mathrm{PT}_{1} \mathrm{~J}_{1}(0.91 \mathrm{~g} / \mathrm{cc})$. Hal ini sejalan dengan hasil penelitian Subagyono et al (2004), dimana intensitas pengolahan berpengaruh terhadap penurunan kerapatan isi dan tanah bertekstur liat dengan pengolahan dua tahap memiliki kerapatan isi yang lebih rendah dibandingkan dengan pengolahan satu tahap.

Penambahan jerami pada saat pengolahan tanah tidak berpengaruh terhadap kerapatan isi, baik pengolahan satu tahap maupun dua tahap. Kerapatan isi (BD) yang dilakukan penambahan jerami lebih kecil dibandingan dengan tanpa penambahan jerami, yaitu yaitu $\mathrm{PT}_{1} \mathrm{~J}_{1}(0.91 \mathrm{~g} / \mathrm{cc})<\mathrm{PT}_{1} \mathrm{~J}_{0}(0.92 \mathrm{~g} / \mathrm{cc})$ dan $\mathrm{PT}_{2} \mathrm{~J}_{1}$ $(0.86 \mathrm{~g} / \mathrm{cc})<\mathrm{PT}_{2} \mathrm{~J}_{0}(0.89 \mathrm{~g} / \mathrm{cc})$. Hasil penelitian Khan et al., (2010), penambahan bahan organik pupuk kandang pertanian secara signifikan mengurangi kepadatan tanah. Jerami merupakan salah satu bahan organik, namun pada percobaan ini, penambahan jerami segar belum berpengaruh pada kerapatan isi, karena jerami membutuhkan waktu yang lama untuk bisa terurai.

Pengolahan tanah dan penambahan jerami tidak berpengaruh terhadap berat jenis partikel (PD). Nilai berat jenis partikel(PD) berbanding lurus dengan kerapatan isi (BD), semakin rendah kerapatan isi (BD) maka nilai berat jenis partikel(PD) juga semakin kecil. Pada Tabel 3 terlihat nilai kerapatan isi terendah berada pada perlakuan pengolahan dua tahap dan pengunaan jerami yaitu $2.19 \mathrm{gr} / \mathrm{cm}^{3}$.

Pengolahan tanah dan penambahan jerami tidak berpengaruh terhadap ruang pori total. Ruang pori total tertinggi adalah pengolahan tanah dua tahap dengan penambahan jerami, yaitu $60.9 \%$. Ruang pori total sangat erat kaitannya dengan kerapatan isi dan berat jenis partikel tanah. Semakin besar nilai berat jenis partikel menunjukan semakin padat tanah dan semakin kecil pori-pori dalam tanah tersebut. Hasil penelitian Nazeer \& Malik (2011), juga menunjukkan pengolahan tanah yang dalam secara signifikan meningkatkan total porositas tanah.

Bahan organik tidak hanya meningkatkan kapasitas penahanan air tanah tetapi juga porsi air yang tersedia untuk pertumbuhan tanaman dan meningkatkan sifat fisik (Khan et al., 2010). Pada percobaan ini (Tabel 2) menunjukkan bahwa intensitas pengolahan dan penambahan jerami berpengaruh terhadap kadar air (pF1, pF2, pF2,54, dan $\mathrm{pF} 4,2$ ).

Pori drainase dipengaruhi oleh ruang pori total, hubungan pori drainase cepat berbanding lurus dengan ruang pori total dan berbanding terbalik degan pori drainase lambat (Gambar 3). Semakin besar ruang pori total maka besar pula pori drainase cepat dan semakin kecil pori drainase lambatnya. Pengolahan tanah berpengaruh terhadap pori drainase cepat dan pori drainase lambat, namun penambahan jerami tidak berpengaruh.

Menurut Setyorini \& Abdulrachman (2009), hancurnya agregat tanah akibat pengolahan tanah dengan pelumpuran menyebabkan porositas dan distribusi ruang pori terganggu sehingga menurunkan kemampuan tanah melewakan air (permeabilitas).

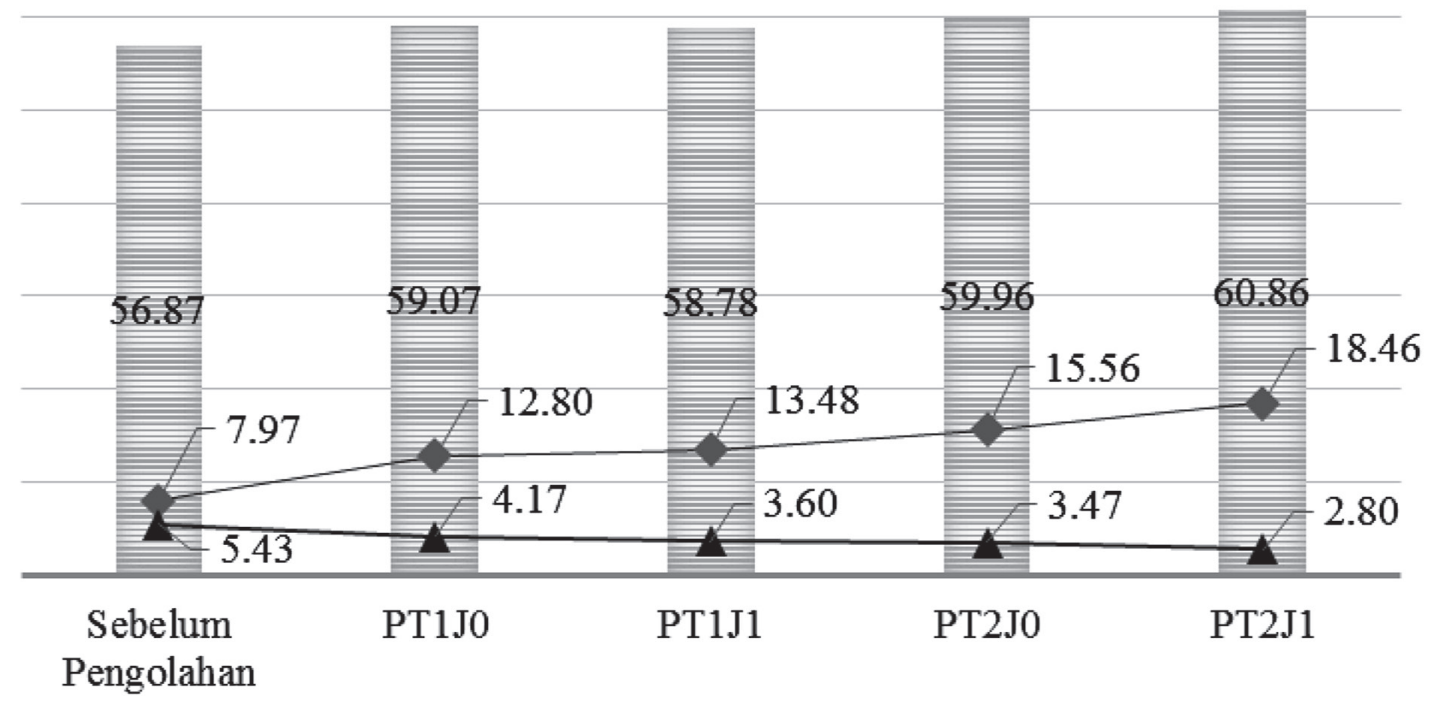

Total Ruang Pori (\% vol) $\longrightarrow$ Pori Drainase Cepat (\% vol) $\longrightarrow$ Pori Drainase Lambat (\% vol)

Gambar 3. Nilai Total Ruang Pori, Pori Drainase Cepat, dan Pori Drainase Lambat 
Penambahan jerami pada saat pengolahan merupakan salah satu penerapan olah tanah konservasi pada lahan sawah. Menurut (Rachman et al, 1973), hantaran hidrolik tanah akan rendah pada awal penerapan OTK, namun meningkat menurut waktu. Pengolahan tanah dan penambahan jerami berpengaruh terhadap permeabilitas. Pada Gambar 4 dapat dilihat, permeabilitas pada pengolahan tanah dengan penambahan jerami lebih besar dibandingkan dengan tanpa penambahan jerami, baik untuk pengolahan satu tahap maupun dua tahap.

Pada percobaan ini, air tersedia pada lahan pengolahan tanah dengan penambahan jerami lebih besar dibandingkan dengan lahan pengolahan tanah tanpa penambahan jerami. Perlakuan yang memiliki air tersedia paling tinggi dibandingkan dengan perlakuan lainnya adalah $\mathrm{PT}_{2} \mathrm{~J}_{1}$ yaitu sebesar $16 \%$ (Gambar 5). Pengolahan tanah dan penambahan jerami berpegaruh terhadap air tersedia. Menurut Eusufzai, Maeda, \& Fujii (2007), jerami padi dapat mengurangi kepadatan tanah dan meningkatkan daya serap air, meningkatkan porositas dan menurunkan bulkdensity. Menurut Bailey (1989); Iqbal et al (2006) bahan organik dapat mempengaruhi sifat fisik tanah seperti struktur tanah akan menjadi lebih remah dan gembur, kemapuan tanah menahan air meningkat dan merangsang granulasi agregat dan memantapkannya.

\section{Kebutuhan air penyiapan lahan padi sawah}

Kebutuhan air untuk penyiapan lahan termasuk kebutuhan air untuk persemaian dan kebutuhan air untuk pengolahan tanah. Pengolahan tanah dan penambahan jerami mempengaruhi sifat fisik tanah, yang merupakan faktor penting dalam menentukan kebutuhan air selama penyiapan lahan padi sawah. Kebutuhan air selama penyiapan lahan untuk budidaya padi sawah di lokasi penelitian disajikan pada Tabel 4. Berdasarkan data pengukuran (Tabel 4), pengolahan tanah dan penambahan jerami berpengaruh terhadap kebutuhan air untuk penyiapan lahan, tetapi tidak ada interaksi antara keduanya. Kebutuhan air penyiapan lahan dengan penambahan jerami membutuhkan air yang lebih banyak dibandingkan dengan pengolahan tanah tanpa penambahan jerami. Kebutuhan air

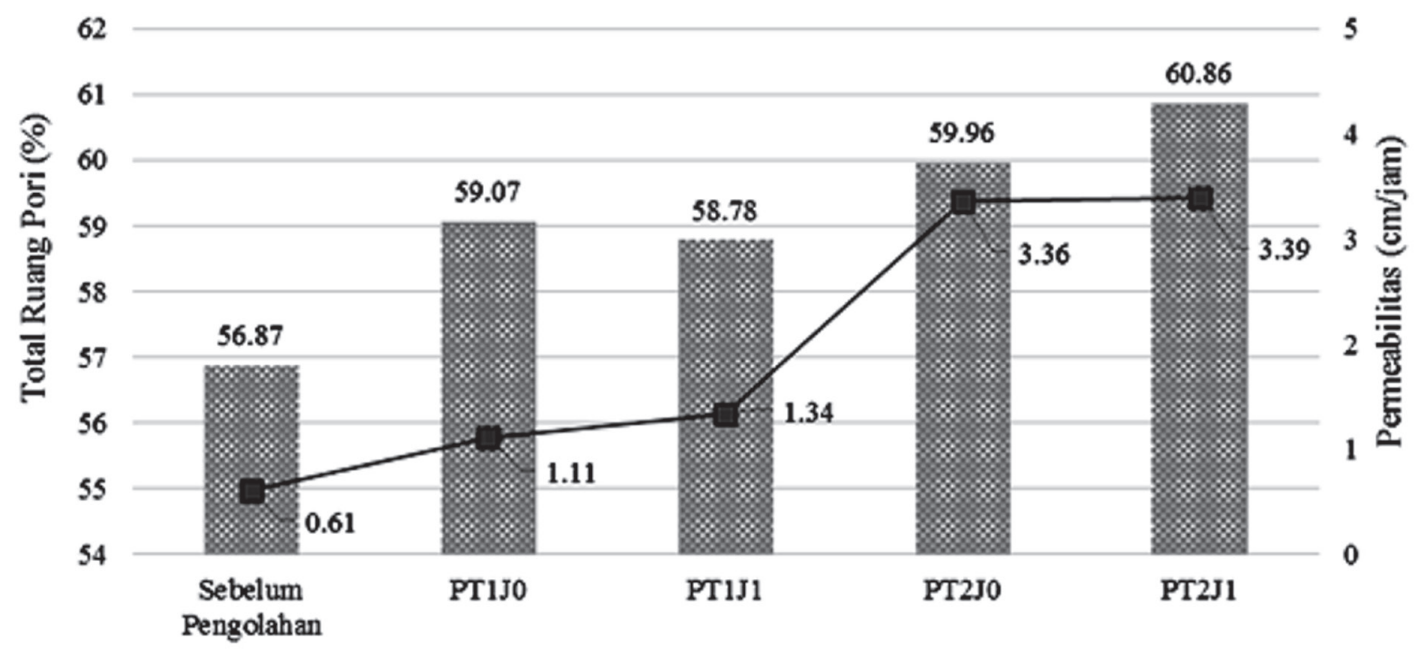

Ruang Pori $\rightarrow$-Permeabilitas

Gambar 4. Nilai Total Ruang Pori dan Permeabilitas

17

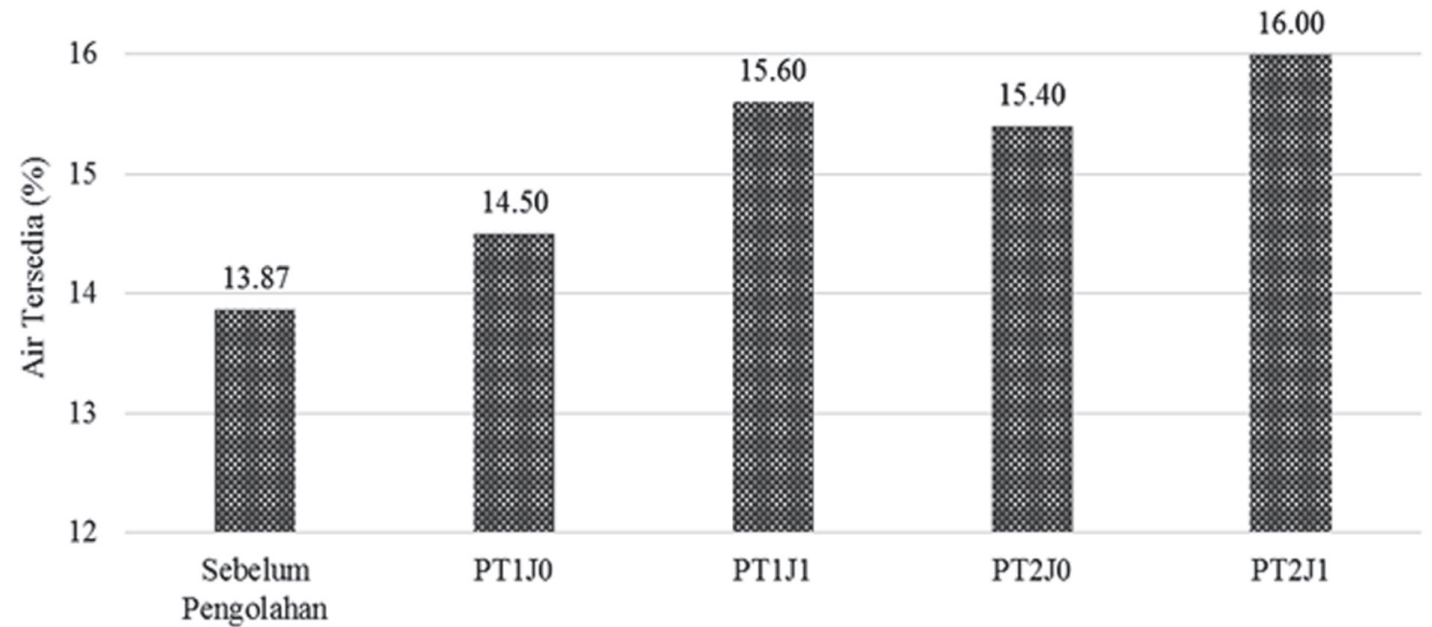

Gambar 5. Air Tersedia 
Tabel 4. Pengaruh Pengolahan Tanah dan Penambahan Jerami terhadap Kebutuhan Air Penyiapan Lahan

\begin{tabular}{lc}
\hline & Keb. Air Penyiapan Lahan $(\mathrm{mm})$ \\
\hline Faktor A & $86.14 \pm 1.28_{\mathrm{a}}$ \\
$\mathrm{PT}_{1}$ & $195.63 \pm 1.55_{\mathrm{b}}$ \\
$\mathrm{PT}_{2}$ & \\
Faktor B & $139.61 \pm 59.85_{\mathrm{a}}$ \\
$\mathrm{J}_{0}$ & $142.16 \pm 60.09_{\mathrm{b}}$ \\
$\mathrm{J}_{1}$ & \\
Faktor A x B $_{\mathrm{PT}_{1} \mathrm{~J}_{0}}$ & $84.97 \pm 0.08_{-}$ \\
$\mathrm{PT}_{1} \mathrm{~J}_{1}$ & $87.31 \pm 0.07_{-}$ \\
$\mathrm{PT}_{2} \mathrm{~J}_{0}$ & $194.24 \pm 0.25$ \\
$\mathrm{PT}_{2} \mathrm{~J}_{1}$ & $197.01 \pm 0.39_{-}$ \\
\hline
\end{tabular}

penyiapan lahan yang terbanyak adalah pengolahan tanah dua tahap dengan penambahan jerami segar sebanyak 15.6 ton/ha $\left(\mathrm{PT}_{2} \mathrm{~J}_{1}\right)$ yaitu sebesar 197.01 $\mathrm{mm}$. Kebutuhan air penyiapan lahan pada percobaan ini lebih rendah dibandingkan dengan kebutuhan air penyiapan lahan pada Kriteria Perencanaan Irigasi 01 oleh Direktorat Jendral Departemen Pekerjaan Umum (1986) yaitu sebesar $250 \mathrm{~mm}$ atau $300 \mathrm{~mm}$ dengan lama pengolahan 30 hari dan tanah bertesktur berat. Terjadinya perbedaan kebutuhan air penyiapan lahan, disebabkan oleh perbedaan lama pengolahan tanah. Hasil penelitian Yanti \& Setiawan (2012), kebutuhan air penyiapan lahan sebesar $292.83 \mathrm{~mm}$, dengan kadar air sebelum pelumpuran sebesar $27.16 \%$ dan lama pengolahan selama 30 hari.

Perlakuan $\mathrm{PT}_{2} \mathrm{~J}_{1}$ membutuhkan air yang paling banyak dalam penyiapan lahan, namun merupakan perlakuan terbaik karena mempunyai air tersedia paling besar yaitu $16 \%$. Pada percobaan ini pengamatan hanya dilakukan pada satu musim tanam, sehingga pengaruh interaksi perlakuan pengolahan tanah dengan penambahan jerami belum terjadi. Menurut Handayanto (1998); Yazid Ismi Intara et al, (2011) bahan organik yang diberikan dalam tanah akan mengalami proses pelapukan dan perombakan yang selanjutnya akan menghasilkan humus. Fitter \& Hay (1998); Intara et al, (2011) menyatakan humus penting, dimana tanah tidak cepat kering pada musim kemarau karena memiliki daya memegang air (water holding capacity) yang tinggi. Humus dapat mengikat air empat sampai enam kali lipat dari beratnya sendiri. Dengan terikatnya air oleh humus berarti dapat mengurangi penguapan air melalui tanah.

\section{Simpulan}

Pengolahan tanah dengan traktor tangan dan penambahan jerami sebanyak 15.6 ton/ha berpengaruh terhadap sifat fisik tanah dan kebutuhan air penyiapan lahan, tetapi tidak ada interaksi antara kedua faktor tersebut. Pengolahan tanah dua tahap dengan penambahan jerami merupakan perlakuan yang membutuhkan air paling banyak dalam penyiapan lahan yaitu sebesar $197.01 \mathrm{~mm}$, tetapi merupakan perlakuan terbaik dengan air tersedia sebesar $16 \%$.

\section{Daftar Pustaka}

Ahmad, N., M. Rashid and A.G. Vaes. 1996. Fertilizer and their use in Pakistan, NFDC Publ. No. 4/96. $2^{\text {nd }}$ Ed. Islamabad. p. 274.

Bailey, H.H. dkk. 1986. Dasar-dasar IImu Tanah. Lampung. Universitas Lampung

Bolan, N., D. Adriano and S. Mahimairaja. 2004. Distribution and Bioavailability of Trace Elements in Livestock and Poultry Manure by Products. Critical Reviews in Environmental Sciences and Technology 34: 29-338.

Direktorat Jendral Departemen Pekerjaan Umum. 1986. Standar Perencanaan Irigasi- Kriteria Perencanaan 01. Badan Penerbit Departemen Pekerjaan Umum. Jakarta.

Dixon, J.B. 1991. Roles of Clays in Soils. Applied Clay Science, (5); 489-503

Epstein E., J.M. Taylor and R.L. Channey. 1976. Effect of sewage Sludge Compost Applied to Soil on some Physical and Chemical Properties. Journal of Environmental Quality 5: 422-426.

Eusufzai, M.K., T. Maeda and K. Fujii. 2007. Field Evaluation of Compost, Sawdust and Rice Straw Biomass on Soil Physical and Hydraulic Properties. Soil.En.Au-Tokyo.Ac.Jp, 3-16. Retrieved from http://soil.en.a.u-tokyo.ac.jp/jssp/db/pdf/107003. pdf

Fitter dan Hay. 1998. Fisiologi Lingkungan Tanaman. Terjemahan. Sri Andani dan Purbayanti Gajah Mada University Press, Yogyakarta

Handayanto. 1998. Pengelolaan Kesuburan Tanah secara Biologi untuk Menuju Sistim Pertanian Sustainabel. Habitat (104); 1-9.

Hanafiah, K.A. 2005. Dasar-dasar IImu Tanah. Jakarta: PT Raja Grafindo Persada.

Hammel, J.E. 1989. Long Term Tillage and Crop Rotation Effects on Bulk Density and Soil Impedance in Northern Idaho. Soil Sci. Soc. Am. J. 53: 1515-1519.

Hartatik, W., dan D. Setyorini. n.d. Pengelolaan Lahan dan Budidaya Padi Sawah dalam Sistem Pertanian Organik. In Sistem Pertanian Organik Mendukung Produktivitas Lahan Berkelanjutan (Vol. 3, pp. 113-139). Retrieved from http://balittanah. litbang.pertanian.go.id/ind/index.php/publikasimainmenu-78/art/446-org

Intara Y.I., A. Sapei, Erizal, N. Sembiring, and M.H.B. Djoefrie. 2011. Affected of Organic Matter Application at Clay and Clay Loam Soil. Jurnal IImu Pertanian Indonesia, 16(2), 130-135. 
Intara Y.I., A. Sapei, Erizal, N. Sembiring, and M.H.B. Djoefrie. 2011. Affected of Organic Matter Application at Clay and Clay Loam Soil. Jurnal IImu Pertanian Indonesia, 16(2), 130-135.

Iqbal, I., T. Mandang dan N. Sumbiring. 2006. Pengaruh Lintasan Traktor dan Pemberian Bahan Organik terhadap Pemadatan Tanah dan Keragaan Tanaman Kacang Tanah. Jurnal Keteknikan Pertanian, 20(3), 225-234.

Korentajer, L. 1991. Review of Agricultural Use of Sewage Sludge: Benefits and Potential Hazards. Water SA. 17: 189-196.

Khan, N.I., A.U. Malik, F. Umer, and M.I. Bodla. 2010. Effect of Tillage and Farm Yard Manure on Physical Properties of Soil. International Research Journal of Plant Science, 1(4), 2141-5447. Retrieved from http://www.interesjournals.org/IRJPS

Mahajan, K.K. 1996. Management of Phosphorus and Farm Yard Manure in Maize-Wheat System in Mid Hills Subhumid Zone of Himachal Pradesh. J. Hill Res., 9(3), 480-485.

Nazeer, S. and A.U. Malik. 2011. Effect of Tillage Systems and Farm Manure on Various Properties of Soil and Nutrient's Concentration. Russian Agricultural Sciences, 37(3), 232-238. https://doi. org/10.3103/s1068367411030153

Pagliai, M., G. Guidi, M. La Mrca, M. Giachetti, and G. Lucamante. 1981. Effect of Sewage Sludge and Compost on Porosity and Aggregation. Journal of Environmental Quality 10: 556-561.
Rachman, A., A. Dariah and E. Husen. 1973. Olah Tanah Konservasi. Retrieved from http://balittanah. litbang.pertanian.go.id/ind/dokumentasi/buku/ lahankering/berlereng8.pdf

Sánchez, C. 2010. Cultivation of Pleurotus Ostreatus and Other Edible Mushrooms. Applied Microbiology and Biotechnology, 85(5), 1321-1337. https://doi. org/10.1007/s00253-009-2343-7

Saraswati, R., dan E. Husen. 2004. Prospek Penggunaan Pupuk Hayati Pada Sawah Bukaan Baru. Retrieved from balittanah.litbang.pertanian. go.id

Setyorini, D., dan S. Abdulrachman. 2009. Pengelolaan Hara Mineral Tanaman Padi. Retrieved from http://www.litbang.pertanian.go.id/special/padi/ bbpadi_2009_itkp_05.pdf

Sial, R.A., E.H. Chuadhary, S. Hussain, and M. Naveed. 2007. Effect of Organic Manures and Chemical Fertilizers on Grain Yield of Maize in Rainfed Area. Soil and Environment, 26(2): 130-133.

Subagyono, K., A. Abdurachman, dan S. Nata. 2004. Effects of pudling various soil types by harrow on physical properties of new developed irigated rice areas in Indonesia. Proceeding of the Subandiono, $R E$.

Yanti, D. dan D. Setiawan. 2012. Analisa Nilai Manfaat Irigasi Pompa Dangkal Ditinjau dari Keberlanjutan Sumber Daya Air untuk Pertanian. Teknologi Pertanian Andalas, 16(1). 